\title{
9
}

\section{Coloniality of Power and the Contours of Contemporary Sport Industries: Fijians in Australian Rugby}

Scott Mackay and Daniel Guinness

Over several days in 2016, conditions became so bad in the Rugby Futures' dormitory in Sydney that the young Fijian men who resided there needed to ask local leaders in the Fijian community for food and other essentials. ${ }^{1}$ Some of the men had previously experienced periods of hunger while looking for work or training for rugby in one of Fiji's regional centres. However, in Australia, things had become worse. The Fijians had moved to Australia under the promise of a clear pathway into professional rugby. Yet, one man reported to us that, instead, they found themselves with a strict curfew, performing manual labour for salaries (75 per cent of which were confiscated by the Rugby Futures' program head for what he called 'board and services'), and unable to control their careers or even their passports. Occasionally, the program head would leave for the weekend, temporarily locking the men out of their only kitchen and food supplies.

\footnotetext{
1 All names are pseudonyms and certain identifying features of individuals and organisations have been altered to preserve anonymity.
} 
Without food or resources to buy food, the men contacted Seva and Va, two members of a previous generation of itaukei (indigenous) migrants. Seva, who had arrived as an aspiring young rugby player 20 years earlier, had learned how to negotiate the labour lines in and out of the rugby industry from another Fijian, Isei. Isei had migrated to Australia in the 1970s - during the first years of Fijian independence, when the nation was beginning to break out of the British colonial social order and was struggling to form relationships with the regional power. In Australia, Seva met and started a family with Va, who had moved from Fiji as a teenager for high school, staying with an Anglo-Australian couple she had met in Fiji. Now, Seva and Va form a prominent part of the Fijian diaspora in Australia, supporting new arrivals and providing a safety net of basic material needs, home-cooked food, a hub for social relations and a place for sharing experiences across generations. They regularly advise new arrivals on how to manage finances and carry out day-to-day chores, find formal and informal work, and balance the demands from family in Fiji with the task of building a new life in Australia. Through locations like Seva and Va's house, collective migration histories, forged over two centuries of relations and migration between Fiji and Australia, shape the experiences of today's migrant workers. However, there is also a formal, institutional aspect of this history.

The contours of rugby-specific contemporary migration from Fiji to Australia are built on historical connections and lines between the two nations. Both nations experienced a colonial system of governance that worked to produce and discipline people to be particular kinds of subjects for labour, while establishing differentiated categories of citizenship based on two different ideas of ethnicity and indigeneity, each originating in colonial thought. As has been shown elsewhere in this volume, the legacy of colonialism persists in current migration and labour regimesin the 'coloniality of power' ${ }^{2}$ of present-day Australia. This approach to coloniality unpacks the intersections between race, gender and other hierarchies that have historically occurred in systems of migration and labour. Further, it shows how aspects of these systems continue to exist, structuring access to labour markets in ways that ensure the subordination of some for the benefit of others. In this case, the historical hierarchies between the two countries were dominated by ethnicised divisions of labour, the exclusion of Fijians from Australia (and its labour force) and the extraction of resources from Fiji by Australian corporations.

2 Quijano, 'Coloniality of Power'; Quijano, 'Coloniality and Modernity/Rationality'. 
In other ways, the struggles of Fijian rugby players are products of very contemporary dynamics. Australian policies of labour governance are heavily influenced by neoliberal forms of governance as the state pursues privatisation and deregulation, ${ }^{3}$ and, as distinct from late capitalism, implements changes to regulate more aspects of life by the market, such as education, healthcare and the environment. ${ }^{4}$ Neoliberal styles of governmentality position individual workers/migrants as responsible for their own position, and as being capable of negotiating fair and equitable contracts from an equal position as employers (including large multinationals and government-backed organisations), ${ }^{5}$ ultimately creating insecurity and precarity for individual subjects. ${ }^{6}$ These logics pervade not only the Australian labour market but also immigration policies. Australian employers are imagined as operating in a global market place, with Australia competing with other countries for the best educated, wealthiest and most highly skilled migrants. Would-be migrants with skills identified by the government as valuable can gain work permits easily, while others are excluded or confined to visa classes with highly restricted rights. In line with neoliberal ideologies, migrants/workers are cast as being responsible for their own ability to compete on the migration labour market. This rhetoric helps to obscure the perpetuation of colonial hierarchy obvious in the preferential passage through Australia's migration and labour regimes granted to migrants from selected countries. This coloniality, while it helps some Fijian migrants, leverages the positive outcomes experienced by the few to coerce the many to accept their position as cheap labour.

Would-be rugby players epitomise the ambivalence of the system, as the men oscillate between very high paying jobs that offer easy pathways to residency and citizenship rights and precarious labour that is entirely 'uncoupled from any possibility of citizenship.'? In Australia, professional rugby union has emerged as a new employer of Fijians, and one that, uncharacteristically, offers high-paying contracts to some new migrants. The professional Australian rugby union clubs, located in Brisbane, Sydney, Canberra and Melbourne, now offer 30 full-time contracts

3 Harvey, Brief History of Neoliberalism, 3.

4 Mirowski, 'Defining Neoliberalism', 434-35; Besnier et al., 'Rethinking Masculinity'.

5 Gershon, 'Neoliberal Agency'; Gershon and Alexy, 'Ethics of Disconnection'; McGuigan,

'Neoliberal Self'; Rose and Miller, Governing the Present.

6 Bourdieu, Firing Back.

7 Stead and Altman, 'Labour Lines and Colonial Power', this volume. 
to rugby players, with starting salaries of around AU $\$ 70,000$, and are actively recruiting itaukei Fijian rugby athletes for their athleticism and skills. ${ }^{8}$ These prospects are alluring to many young indigenous men and some women, who see rugby as the most natural and lucrative possibility for migration and employment. ${ }^{9}$

The economies of hope that motivate young itankei men have resulted in a rapid increase in the number of Fijians entering Australian clubs, including, although in smaller numbers, Australia's National Rugby League, a professional competition of a different code of rugby. However, the majority of Fijian athletes play for amateur clubs. Without high-paying contracts, they find themselves working outside of sport-sometimes exploited or left to fend for themselves on the margins of Australia's labour markets and migration regimes—as seasonal workers, manual labourers or religious workers.

Individual and collective mobility aspirations are intertwined with understandings and histories of what it is to be Fijian in a postcolonial nation and global world. Numerous periods of multi-sited field work in Fiji and Australia with Fijian rugby players and their families demonstrate the important role that Australian rugby plays as a site of hope for young Fijian men today. Once they arrive in Australia, these men encounter the legacy of past connections between Australia and Fiji-the symbolic, political and cultural contours that continue to shape the lives of young migrants. These contours have been formed in relation to those that structure the working opportunities of Indigenous Australians. The experiences of Fijian athletes highlight the intertwining of Australian and Fijian migration regimes, labour markets and social worlds, exposing the contours of global and domestic labour markets.

8 During the field work period there were five professional rugby franchises in Australia. However, at the end of the 2017 season, one of the five, the Perth-based Western Force, was disbanded.

9 In the last five years, small numbers of Fijian women have migrated to Australia in pursuit of professional rugby careers, including some in Rugby Futures. There are significantly fewer opportunities in Australian rugby for women than men, with only the national $7 \mathrm{~s}$ squad receiving a salary from the Australia Rugby Union, as compared to a 7s squad and four Super Rugby franchises, each with 30 full-time professional athletes. 


\section{The Historical Lines between Australia and Fiji}

Australia and Fiji share long histories of engagement framed by their respective, yet very different, colonisation by the British. Defined by an ambivalence reflective of Australia's broader kinship with its Pacific neighbours (borrowing from Teaiwa and Mallon in a New Zealand context $t^{10}$ ), Australia-Fiji histories have often been erased or relegated to the footnotes of Australian history. This is symptomatic of an Australian historiography that 'has been reluctant to acknowledge [its] constitutive imperial ambition and the long history of exploitation of labour and land that has marked Australian relations with the Pacific'. ${ }^{11}$ When AustraliaPacific histories are illuminated, they often neglect the concurrent Australian violence towards, and dispossession of, Indigenous Australians (an exception being the work of Tracey Banivanua Mar ${ }^{12}$ ), an 'academic division of labour' that reflects governmental tendencies to 'treat "whiteAboriginal" and "Anglo-ethnic" relations as mutually exclusive spheres. ${ }^{13}$

Formed via the reliance of the newly established British colony of New South Wales on Fijian and broader Pacific resources and labour, the earliest Australian-Fiji kinships stretch back over 200 years. In 1809, New South Wales informally declared Fiji's islands as lying within its political jurisdiction for economic and geopolitical reasons. ${ }^{14}$ Not officially annexed, Fiji eventually became a separate British colony in 1874 . The lure of economic opportunities brought many white Australian people and businesses to Fiji. In fact, such was the connection between Australia and Fiji in the late nineteenth century that, in the two decades leading up to Australian Federation in 1901, dialogue was entered into between Australia's colonies and Fiji on its possible inclusion within the soon-to-be Commonwealth of Australia; however, this union did not eventuate.

10 Teaiwa and Mallon, 'Ambivalent Kinships?'.

11 Lake, 'Island Empire', 411.

12 Banivanua Mar, Violence and Colonial Dialogue; Banivanua Mar, 'Shadowing Imperial Networks'.

13 Stephenson, 'Beyond Black and White', 5; Hage, White Nation.

14 Gammage, 'Early Boundaries'. 
Both Australia and Fiji developed systems of labour governance that were clearly structured around imagined racial divisions. The BritishFijian colony built its future on large-scale sugar industries in the second half of the nineteenth and early part of the twentieth century, utilising cheap, imported, indentured coloured labour to maximise economic profit. While the British-Australian colony of Queensland (established in 1859) pursued similar projects by acquiring labour predominantly from the Melanesian islands of New Caledonia, Papua New Guinea, Solomon Islands and Vanuatu (collectively known as South Sea Islanders ${ }^{15}$ ), Fiji sought its labour for the most part from India. ${ }^{16}$ Descendants of Indian indentured labourers and those who migrated to Fiji as merchants during the first half of the twentieth century identify as Indo-Fijian and represent the second-largest ethnic group in Fiji. Arguments against the use of white labour in Fiji and Queensland shared similarities in that they were based on price, availability and the 'conventional wisdom' that positioned plantation labour in tropical climates as fatal to European workers. However, the rationale for the omission of indigenous labour differed. A paid and regulated Aboriginal Australian workforce was not considered in Queensland, as Aboriginal Australians were viewed as 'uncivilisable' and a 'dying race'. By contrast, indigenous Fijians were prevented from working as plantation labour on the grounds that it would be 'detrimental to [the] traditional Fijian way of life. ${ }^{17}$ The colonial-indigenous engagement in Fiji was based on the (partial) recognition of itaukei sovereignty, which contrasted markedly with the concurrent definition of Indigenous Australians' land and resources as terra nullius and, thus, justifiably claimable without negotiation and/or a treaty.

Australia significantly influenced the economic and social dynamics of early and mid-twentieth-century Fiji, establishing the unilateral dynamics that have predominantly defined Australia and Fiji's relationship. In 1907, the Australian Government forcibly deported 427 South Sea Islanders (half of whom were from the island of Malaita in the Solomon Islands) to Fiji under the Pacific Island Labourers Act 1901, part of a broader

15 Less than 1 per cent of the 60,000 South Sea Islanders brought to Queensland between 1863 and 1904 came from Polynesian islands-Samoa, Niue, Kiribati, Tuvalu and Rotuma (today a Fijian dependency).

16 Pacific Island labour — predominantly from Solomon Islands and New Hebrides (Vanuatu) extensively used in the preceding cotton industry, was also employed.

17 Lawson, 'Military Versus Democracy', 138. 
bipartisan policy decision to construct a 'White Australia'. ${ }^{18}$ After World War II, Australia, in collaboration with the British and New Zealand governments, also forcibly resettled the indigenous population from the Kiribati island of Banaba to the Fijian island of Rabi, following the catastrophic environmental degradation caused on the island by decades of phosphate rock extraction and exportation for agricultural purposes by the three nations. ${ }^{19}$ The movement of people was in part facilitated by the dominance that Australian companies had asserted over Fiji's sugar, gold, banking and fledgling tourism industries.

Under the Australian Government's Immigration Restriction Act 1901, non-white Fijians were restricted from entering Australia until 1958 when it was repealed by the Migration Act. This established a universal visa and entry permit system yet did not promote non-white visitation or residency. Australian census figures documented an indigenous Fijian presence of only 45 in 1911 and 99 in $1954 .{ }^{20}$ Most of these were granted temporary access for family reunion (mostly by way of marriage to Australian citizens), religious and sporting purposes (by way of acquiring a certificate of exemption from the Immigration Restriction Act). Entry for religious purposes included itankei missionaries who were brought over by the Methodist Overseas Missions of Australasia to Arnhem Land in the Northern Territory from 1928 through to the mid-1970s to convert and 'civilise' Aboriginal Australians. This replicated a broader 'missiological method' previously utilised in other parts of the Pacific that substituted European missionaries in favour of Pacific Island missionaries to more effectively Christianise indigenous peoples. ${ }^{21}$ Instances of itaukei and Indo-Fijian's overstaying their temporary residency in Australia often resulted in their swift deportation by Australian immigration officials.

18 Māori exclusion was implicated in continued Australian efforts post-Federation to entice New Zealand to join its Commonwealth (see Hamer, "Unsophisticated and Unsuited"). See also, Moore, Making Mala.

19 Teaiwa, Consuming Ocean Island.

20 'Census of the Commonwealth of Australia, 1911: Part VIII. Non-European Races', Melbourne: Commonwealth Bureau of Census and Statistics, 1911. Accessed 14 March 2019, www.ausstats. abs.gov.au/ausstats/free.nsf/0/F8A631CD75497EA6CA25783900132215/\$File/1911\%20Census \%20-\%20Volume\%20II\%20-\%20Part\%20VIII\%20Non-European\%20Races.pdf; 'Census of the Commonwealth of Australia, 1954: Supplement to Part I. Cross Classifications of the Characteristics of the Population: Race', Canberra, 1954. Accessed 14 March 2019, www.ausstats.abs.gov.au/ ausstats/free.nsf/0/D26840459C2A2338CA25787200212D27/\$File/1954\%20Census\%20-\%20 Volume\%20VIII\%20-\%20Part\%20I\%20SUPPLEMENT\%20AUSTRALIA\%20Characteristics \%20of\%20Population\%20-\%20Race.pdf.

21 Kadiba, 'Methodist Mission', 103. 
The policing was so stringent that, in 1965, Nancy Prasad, a six-year-old Indo-Fijian girl, was taken from family members who were legally allowed to reside in Australia and deported to Fiji due to the expiration of her travel permit. This highly publicised event demonstrated to the world the longevity and severity of Australia's racialist immigration policies, evoking national and global outcry that helped to expedite the dismantlement of seven decades of explicit race-based political discourse and policy.

\section{Contemporary Links between Australia and Fiji}

Despite Australia's official transition from an explicitly 'white' to a 'multicultural' nation under the Whitlam Labor Government (1973-75), its immigration policies post-1973 targeted highly skilled, non-white migrants, a position that hardened in the wake of John Howard's election as prime minister in 1996. From a Fijian perspective, contemporary Australian immigration policies are contoured by the coloniality of power, as they restrict migration in ways that continue to be correlated with colonial-era divisions of labour.

Australian immigration pathways for highly skilled migrants have favoured Indo-Fijians over indigenous Fijians, as a consequence of their higher educational attainment brought about by colonial policies that divided education and labour in Fiji on ethnic grounds. ${ }^{22}$ Australian population statistics reflect this; out of 56,979 Fijian-born people in Australia in 2011, 35,411 identified as Fijian-Indian or of Indian ancestry. By contrast, only 12,485 identified as being of Fijian ancestry-loosely assumed to be those who identify as indigenous. ${ }^{23}$

Four indigenous-led military coups have taken place since the British granted Fiji independence in 1970 (two in 1987 and one each in 2000 and 2006). These have motivated Indo-Fijian migration to Australia and other parts of the world (i.e. New Zealand, Canada and the United States). Commonly framed in simplistic terms as the result of interethnic tensions between itaukei (54 per cent of the population) and IndoFijian's, ${ }^{24}$ these undertakings have had significant effects on Fiji's political

22 Sharma et al., 'Fiji: Evolution of Education'.

23 'Community Information Summary: Fiji-Born'.

24 This simplistic framing elides the more intricate dynamics at play. See Lal, Broken Waves. 
and economic landscape, as well as emigration. Indo-Fijians, notably in the post-coup years, have witnessed the diminishing of their economic and political rights, resulting in large rates of emigration. They have gone from making up over half the total population of Fiji in the mid-1980s to comprising just 38 per cent. ${ }^{25}$ Simultaneously, there has been a rise in youth unemployment rates for all groups as a result of a combination of post-coup economic sanctions from trading partners, including Australia; the failure of 1990s structural adjustment to stimulate economic growth in Fiji as it entered global markets; and significant rural to urban migration.

Migration routes for indigenous Fijians to Australia post-1973 have, for the most part, built upon pre-existing pathways of temporary visas connected to family reunion, education (Australian Governmentsponsored scholarships), religion and sport. Since the 1990s, a migratory disposition has developed among many indigenous Fijians in which 'the future is synonymous with exile and emigrating'. ${ }^{26}$ However, Fiji's lack of postcolonial migration alliances, such as the Cook Islands, Niue, Tokelau and Samoa have with their respective current or former colonial administrator, New Zealand, inhibits itaukei mobility. Many Cook Islanders, Niueans, Tokelauans and Samoans have New Zealand citizenship status, granted either by birth or the uptake of immigration schemes, which allows them to enter Australia under the bilateral TransTasman Travel Arrangement (TTTA) signed by Australia and New Zealand in 1973. The TTTA affords citizens of each country the right to free travel, work and indefinite residence in both nations. By contrast, Fijian migrants find it difficult to obtain citizenship or permanent residency in either Australia or New Zealand, which significantly limits their possibilities in the labour market and their access to state-provided social security services.

A small number of itaukei (and Indo-Fijians) have been able to follow the TTTA route to Australia. This is reflected in statistics that show that 2,858 of Australia's Fiji-born population in 2008 held New Zealand citizenship. ${ }^{27}$ Yet, this path produces its own insecurities. Initially, when the TTTA was signed in 1973, a host of bilateral agreements accompanied

25 Connell and Voigt-Graf, 'Towards Autonomy'; Trnka, State of Suffering.

26 Guinness and Besnier, 'Nation, Nationalism, and Sport', 1131; Macpherson and Macpherson,

The Warm Winds. The migratory disposition resembles the ideas of 'a good and happy life', 'development dreams', and the operation of mana, which motivate and steer migration of other Pasifika people, as described by Faleolo, Stead, and Standfield and Stevens elsewhere in this volume.

27 Bedford and Hugo, 'Population Movement', 57. 
it, ensuring that citizens from both countries enjoyed access to social security services and voting rights in Australia and New Zealand. However, Australia has unilaterally withdrawn most of these rights to New Zealand citizens over time. Simultaneously, it has made it extremely difficult for New Zealand citizens to acquire Australian permanent residency and, thus, Australian citizenship (while still according them free access and the right to work and reside indefinitely in Australia). New Zealand citizens in Australia are denied access to unemployment and sickness benefits, youth allowances, emergency public housing and student and trade support loans, and are prevented from voting (as discussed in detail by Faleolo in this volume).

Rather than as a response to economic concerns (i.e. the cost of New Zealand citizens on Australia), some commentators frame Australia's policy changes in terms of race, arguing that Australia's concerns are not about the number of New Zealanders entering the country, but the type (i.e. Pacific Island people). ${ }^{28}$ This is an example of how the historical legacy of 'White Australia' continues to reproduce itself. Pacific Islanders who enter Australia via New Zealand have been defined as 'queue jumpers'; that is, 'inauthentic' New Zealanders who possess few of the skills (social and economic) required by other immigrants, but instead take advantage of what is sometimes described as New Zealand's 'raceprivileging' immigration policies. Australia's legislative changes seek to deter New Zealand citizens of low socio-economic status - a population that includes a disproportionately high number of Pacific peoplefrom migrating to Australia. However, to comply with Australias Racial Discrimination Act 1975, the policy changes apply to all New Zealanders.

An important new emigration pathway for itaukei was established in 2015 when Australia allowed Fijians to apply for non-skilled seasonal work visas as part of its broader Seasonal Worker Programme (SWP) established in 2012. ${ }^{29}$ Fiji and other Pacific Island nations had long called for a partnership of sorts with Australia; as early as 1971, Fiji's first prime minister, Ratu Sir Kamisese Mara, had labelled Australia's continued opposition to migration from Pacific Island nations as racist. ${ }^{30}$ However, Fijians arriving as part of the SWP have no chance of transitioning to

28 Hamer, "'Unsophisticated and Unsuited"; Mackay, 'Australia in the Pacific'.

29 See Stead, and Nishitani and Lee (this volume), for more detailed analyses of the seasonal worker programs from a broader Pacific perspective.

30 Mara quoted in Connell, 'Emigration from the South Pacific'. 
permanent residency visa status, which raises questions about reciprocity and the power imbalance that defines Australian-Fiji kinship. For some Fijians, exploitation has come to define their seasonal work experience in Australia. On 25 February 2016, the Australian Broadcasting Commission aired a report on 7.30, its flagship current affairs program, claiming that a Fijian worker brought to Australia as part of the SWP received AU\$58.80 for one week of full-time work from a government-approved employer. Subsequently, 13 out of 20 workers employed by that employer walked off the job. ${ }^{31}$

Regardless of their pathways into Australia, the country is home to a large population of itaukei migrants who exist as part of a precarious workforce. Rural towns such as Griffith in New South Wales have been home to groups of Fijians (itaukei and Indo-Fijians) seeking to build a new life for at least 20 years. $^{32}$ Such places have agricultural-based economies and high demands for 'low' or 'unskilled' workers, and, importantly, are geographically isolated from Department of Immigration and Border Protection offices, allowing Fijians who overstay their visas to find work and form a local community. Fijian communities also exist in low socioeconomic neighbourhoods in some major cities (especially Sydney, Melbourne and Brisbane), where undocumented Fijian workers can find refuge and anonymity in a large population. Fijians who overstay their visas reside and work in Australia under conditions that allow for exploitation in the labour market and necessitate the contravention of migration regulations - both products of the ongoing coloniality of power. It is likely that some of the seasonal workers will end up in communities such as these. On 13 October 2016, an article in the Fiji Times reported that 18 out of 137 seasonal workers had not returned to Fiji upon expiry of their visas. ${ }^{33}$ It is against this backdrop that rugby offers greater promise to would-be Fijian migrants.

31 Australian Broadcasting Corporation, 7.30, 25 February 2016.

32 Schubert, 'Griffith's Transnational Fijians', 135.

33 Litia Cava, '18 Seasonal Workers From Fiji Didn't Return From Australia', Fiji Times, 13 October 2016, www.pireport.org/articles/2016/10/12/18-seasonal-workers-fiji-didnt-return-australia. 


\section{Historical Contours of Fijian and Australian Rugby}

Rugby has played a significant role in pre- and post-independence nation building in Fiji. British colonial agents-military officers, police commanders and schoolmasters-introduced rugby to Fiji in the late nineteenth century, utilising it to promote the doctrine of muscular Christianity, thereby supporting broader colonial attempts to control indigenous masculinities throughout the British-Pacific. ${ }^{34}$ More recently, rugby has become an important way of building a Fijian sense of themselves as a nation in the world. Success at an international level in both the 7-a-side and 15-a-side formats of the sport has served as 'a medium of symbolic resistance against post-colonial marginality' and as a way 'of asserting an alternative collective self-definition', ${ }^{35}$ albeit in a context in which many indigenous Fijians see their experience of colonialism in a favourable light.

In many respects, the contours of Fijian rugby mirror and sometimes reinforce the shape of post-independence Fiji. Rugby articulates with militarism as a dual site for the reflection and facilitation of a contemporary Fijian nationalism that is intensely gendered and indigenised (as well as Christianised). ${ }^{36}$ Through the overwhelming predominance of indigenous men playing rugby at all levels of the game, to the exclusion of women and Indo-Fijian men, ${ }^{37}$ the sport emphasises a bati (warrior) form of the nation, clearly associated with indigenous men. ${ }^{38}$ Casual games of rugby played in villages and urban public spaces, and more formal rugby in schools and clubs, are crucial sites for the socialisation of a masculinity that emphasises a strong, fast and powerful athletic body, coupled with a Christian discipline and respect for indigenous social order. Through the national team, which is wildly popular and watched fanatically by a broad range of Fijians, this form of indigenous masculinity is promoted as being the essence of Fiji, both internally and to the increasing global audience for the sport. Playing the sport becomes a more meaningful activity because of its associations with ethnic, gender and national identities.

34 Besnier, 'Sports, Bodies, and Futures'.

35 Kanemasu and Molnar, 'Negotiating Gender and Sexuality'.

36 Teaiwa, 'Articulated Cultures'.

37 Besnier and Brownell, 'The Untold Story'; Kanemasu and Molnar, 'Negotiating Gender and Sexuality'.

38 Presterudstuen, 'The Mimicry of Men'. 
Rugby in Australia has taken a different trajectory and has acquired a different set of meanings. Unable to solidify itself as the pre-eminent sport of the Australian nation, or even one of its six states and two territories, rugby has long been associated with the small confines of Sydney's wealthy north-eastern suburbs, although this is changing. Within the main rugbyplaying states (New South Wales and Queensland), rugby's biggest and more popular rival is rugby league. Distinguishable by rules and skillsets, the two sports have historically also been differentiated socially, with player and fan bases split loosely on issues of 'national loyalty, political affiliation, class, sectarianism, parochialism, sporting ethos and amateurism. ${ }^{39}$ Rugby is situated as the footballing code of middle- to upper-class, private school-educated, Liberal voters; this British form is influenced by an ideal of amateurism that emphasises both a player's technical ability and attributes as a 'gentleman'..$^{40}$ By contrast, rugby league is cast as the sport of working-class, state school-educated, anti-establishment Labor voters; rather than amateurism, it supports financial remuneration for playersthat is, professionalism. This dichotomy has never represented the reality of there being a significant overlap of players and spectators.

Also dissimilar to the Fijian context was rugby's exclusion of Aboriginal Australian participation. Rugby in Australia was never used as a tool for colonial control of indigenous masculinity. Australia's experience of colonisation-overt violence towards, and segregation and confinement of, an Indigenous people who were deemed 'uncivilisable' and soon to be 'extinct'-justified their omission from the game. Despite changes in racial discourse and the dismantling of race-based policies over time, the continued lack of Indigenous participation reflects their ongoing, systemic exclusion. Of the 917 rugby players who have represented Australia in test rugby since 1899, only 13 have been Aboriginal (not including Wendell Sailor who is a Torres Strait Islander); the first was Lloyd McDermott in $1962 . .^{41}$

39 Horton, 'Land of the Wallabies', 1620.

40 Blackledge, 'Rationalist Capitalist Concerns'.

41 This figure was correct in 2017. Lloyd McDermott's time in the Wallaby team was not without difficulty in an era of overt racism. In 1963, he refused to tour apartheid South Africa as an 'honorary white'. 
Fijian involvement in Australian rugby has its roots in the national team's first tour of Australia in 1952, and subsequent tours in 1954 and $1961 .^{42}$ The 1954 Fijian rugby tour of Australia had a significant, yet inadvertent, effect on Fijian participation in Australian rugby league. During the British rugby league team's tour of Australia, Arthur Walker, manager of the British team and chairman of the Rochdale Rugby League Club in Britain, watched the Fijian rugby team beat Australia in Sydney in the second and final test match. Subsequently, Walker began conversing with a number of Fijian rugby players, encouraging them to move to Britain, convert to rugby league - a sport not played in Fiji at that time ${ }^{43}$ and take up professional contracts with his Rochdale club. One player to do so was Apisai Toga, who signed with Rochdale in $1965 .{ }^{44}$ After playing for two years in Britain, Toga moved to Sydney, signing with the St George Dragons, known as the most inclusive club in the New South Wales' Rugby League, in 1968. Toga was joined at the club by his brother, Inosi, a year later. The Toga brothers were the first of what today is a swell of professional Fijian players excelling at the sport in Australia. ${ }^{45}$ Their arrival in 1968 and 1969 occurred only a few years after the deportation of Nancy Prasad in 1965. The fact that the brothers were able to play in Australia during the era of 'White Australia' indicates that they enjoyed a special status, arguably due to their position as athletes or having links to a well-established club.

42 The touring rugby teams were not the first Fijian sporting teams to enter Australia. That took place in the summer of 1907-08, when the Fijian national cricket team visited. Comprising only one non-itaukei player, the team attracted crowds upward of 9,000 people with interest centering on a paradoxical curiosity in the 'savage', and cricket's ability as a colonial tool to 'tame' the 'native' (see Anae, "'Very Scanty Covering"'). Illustrating a mastery of the sport while infusing indigenised elements to their performance, the team proved to be tough competition for Australian state, university, and district teams. Special permission to enter under the 'White Australia policy' was granted by the Australian Government as a result of the team's sponsorship by the governor of Fiji at the time, Sir Everard im Thurn (who was also the high commissioner of the Western Pacific).

43 Until the early 1990s, rugby union was the only code played in Fiji. Rugby league was founded in Fiji as a solution to a power struggle between the chiefly elite and the military leadership that had gained significant control of national politics after the 1987 coup led by Sitiveni Rabuka. Specifically, the formation of the Fiji Bati as the national rugby league team allowed Rabuka to be appointed to the symbolically important position of president of a rugby organisation without directly challenging the authority of Ratu Sir Kamisese Mara, who was president of Fiji and of the Fijian Rugby Union, and had been Fijian prime minister from independence in 1970 until 1987 (see Teaiwa, 'Articulated Cultures').

44 Other Fijians to sign for Rochdale in this period were Jo Levula and Orisi Dawai in 1961, Voate Drui and Liatia Ravouvou in 1962, and Litai Burogolevu and Gideon Dolo between 1965 and 1967. 45 In 1973, Apisai died suddenly at a team training session, the tragic result of tetanus poisoning from an unattended coral injury acquired while home in Fiji during the off-season. Apisai Toga played 103 games for St George (65 in first grade) over five seasons. Inosi Toga continued to play for St George through to 1974. 


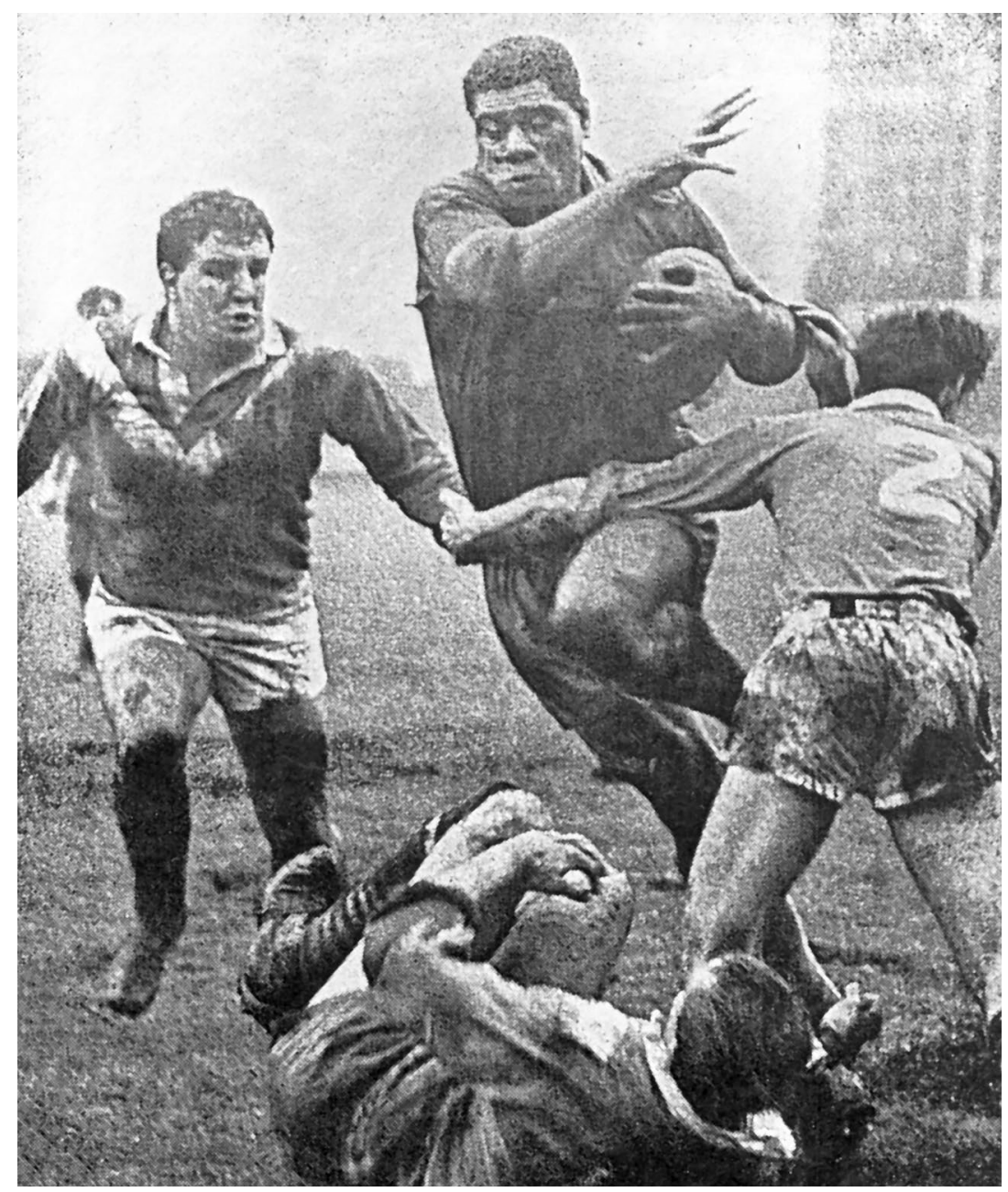

Figure 9.1: Apisai Toga in action.

Source: Unknown; photograph courtesy of Rochdale Hornets Heritage Committee.

\section{Fijians in the Australian Rugby Industry}

In the past 25 years, rugby has taken on extra significance for itaukei men as a rare means to access geographical and social mobility. With the professionalisation of rugby union in 1995, full-time professional teams in prominent rugby-playing countries, such as France, the United Kingdom, New Zealand, Japan and Australia, have grown to the point where they can now offer some Fijians contracts worth as much as AU\$80,000 a month, 
greater than the collective incomes of some extended families living in Fijian villages, and certainly far higher than the salaries available in Fiji. Further, rugby players who have success overseas remain in the spotlight in Fiji, where their achievements are well-known to many, bringing acclaim and respect to their parents, extended families and villages, all of which are partially credited for the individual success of young men. This respect continues even when the athlete decides, for financial and/ or career reasons, to represent other nations-a sign of the 'globalised nationalism' that is emerging as the postcolonial norm for the island nation. ${ }^{46}$ Consequently, several hundred Fijians have moved to different corners of the globe to apply their trade, 'adapting to and being adopted into the very different cultures of their host clubs' and countries. ${ }^{47}$

Australia is a significant site on the global rugby circuit. Across all levels (professional and amateur), and including its national side, the Wallabies, an increasingly visible Fijian presence is evident in the men's game. Surnames such as Naivalu, Kuridrani, Kerevi and Koroibete have become common, albeit awkwardly pronounced, household names among Australia's predominantly white, middle- to upper-class rugby-supporter base. Twelve itaukei men have been selected since Acura Niuqila became the first Fijian to represent the Wallabies in 1988. However, the bulk of the elite Fijian players have been recruited during the professional era.

The professionalisation of rugby union in Australia has featured processes of mediatisation, corporatisation and commoditisation, which have been common in global sport industries since the 1980s, and which arise from neoliberal ideologies of deregulation and free enterprise. ${ }^{48}$ These processes have greatly increased the possibilities for a career as a rugby athlete. Simultaneously, new demands have been introduced on athletes within the newly corporatised professional sporting teams to meet the standards of 'professionalism', an emic term that encompasses the behaviours and dispositions believed to be required of a professional player. ${ }^{49}$ Lucrative pay packages have been able to not only motivate migration from Fiji, but also attract rugby league stars to switch codes, including the signing of Fijian-born Lote Tequiri in 2003 at the peak of his rugby league career with the Brisbane Broncos.

46 Guinness and Besnier, 'Nation, Nationalism, and Sport'.

47 Guinness, 'The Battle for Talent'; Schieder, 'Fiji Islander Rugby Union Players'.

48 Andrews and Silk, Sport and Neoliberalism; Miller et al., 'Modifying the Sign'; Scherer and Jackson, Globalization, Sport and Corporate Nationalism.

49 Besnier et al., 'Rethinking Masculinity'. 
While some well-known Fijians have been recruited directly to professional sides from Fijian teams, other Fijian men, and now women, travel more circuitous routes to careers. Some Fijian boys migrate independently of their families during high school to take up scholarships offered by major rugby-playing schools in New Zealand and Australia (e.g. Kinross Walaroi School). These schools often have links to the professional rugby clubs, acting as part of the feeder system that identifies and trains talented players, some of whom are later recruited into academies where they are joined by other Fijians who have migrated to play for amateur club teams. The academies provide specialist training to improve rugby skills, enhance athletic potential and teach the requirements of 'professionalism'. This amounts to a significant form of disciplining of young men to perform certain types of labour-in this case, as highly valuable athletes.

In several Australian cities, rugby union is making special efforts to engage and recruit young Fijians and other Pacific Islanders into their rugby development systems. Many coaches, managers and player agents believe that Pacific people have rugby in their 'blood'. ${ }^{50}$ In ways that mirror what occurred previously in New Zealand, ${ }^{51}$ there has been significant growth in Pacific participation in Australian rugby. Their increased presence is frequently discussed in the mainstream media in New South Wales and Queensland, ${ }^{52}$ and is normally explained in terms of their physical attributes and 'warrior element', as encapsulated by journalist Spiro Zavos in his article 'The Browning of the Wallabies'. ${ }^{53}$ Some recruiters, such as former New South Wales Rugby League Development Officer Frank Barrett, believe that Pacific Islanders' physical attributes are complemented by their upbringing in a 'tough, hard culture ... that has bred them for a physical game like rugby league'. ${ }^{54}$ Fijians are widely sought after for their large size, speed, power and skills with the ball. The best are regarded as extremely valuable assets to any team.

50 McDonald, Belanji and Derham, 'It's in the Blood'; McDonald, 'Developing "Home-Grown" Talent'.

51 Teaiwa and Mallon, 'Ambivalent Kinships'; Grainger, 'Browning of the All Blacks'; Grainger, Falcous, and Newman, 'Postcolonial Anxieties'.

52 Daniel Lane, 'Islanders in Junior Leagues, It's a Really Big Issue', The Sydney Morning Herald, 16 July 2006, www.smh.com.au/news/league/islanders-in-junior-leagues-its-a-really-big-issue/2006/07/ 15/1152637922188.html.

53 Zavos, 'The Browning of the Wallabies'.

54 Barrett quoted in Daniel Lane, 'Islanders in Junior Leagues, It's a Really Big Issue', The Sydney Morning Herald, 16 July 2006, www.smh.com.au/news/league/islanders-in-junior-leagues-its-areally-big-issue/2006/07/15/1152637922188.html. 
However, coaches are wary when hiring players from the Pacific Islands who have not been through training pathways that teach professionalism, either in Australia or New Zealand. Pacific players are ascribed with physical and cognitive shortcomings attributed to their biology and culture that are not applicable to non-Pacific (Anglo-Australia) players, leading to positional segregation within the labour market. Within rugby league and rugby union hierarchies, some observers view Pacific rugby players as only able to play a 'jungle ball' game-athletically impressive, but ill-disciplined. ${ }^{55}$ Stories circulate about star recruits who could not fit in with team cultures or were not able to learn the complicated strategies that elite teams use. These stories partly derive from the experiences of a few high-profile migrants from Fiji in the early 2000s, but also feed into stereotypes about exotic, hyper-masculine men that linger from the colonial era. ${ }^{56}$ Positive and negative judgements are not attached equally to all Fijians, and rugby migrants fall into two distinct classes of workerthose who have been through professional rugby pathways and those who have not.

Today, the professional system is also establishing itself directly in Fiji, with the formation of three formal academies at Nadi, Suva and Sigatoka that train school-age Fijian rugby players and have links to professional French franchises. More informally, scouts from major rugby league and union teams attend amateur games in Fiji on the lookout for outstanding athletes, run open-call training camps in major population centres to locate potential recruits and have even been known to offer deals to men playing touch rugby on the beaches that flank popular resort hotels (stories of recruitment from obscurity are retold among young men in training in the hope that they too will be chosen). Some of these routes are well established, particularly those to schools, and some young men are well supported and receive an education that can provide opportunities outside of rugby.

Yet, many promises made by recruiters are not fulfilled. Some clubs (from many countries, not just Australia) withhold payments to athletes, do not provide accommodation, employment and transport as promised, and fail to provide exposure to professional rugby opportunities. Moreover, many

55 Brett Kimmorley, 'Brett Kimmorley's NRL Round Six Review: Warriors Back to Jungle-Ball, Cronulla Learning How to Win', Fox Sports, 9 April 2012, www.foxsports.com.au/nrl/nrl-premiership/ brett-kimmorleys-nrl-round-six-review-warriors-back-to-jungle-ball-cronulla-learning-how-to-win/ news-story/b8fcc0cca35b005ffdce56e6d2a55223?sv=703b4a65edcc546757b28e896d637a22.

56 Besnier, On the Edge of the Global. 
Fijians simply do not realise that the remuneration offered will barely cover their basic living costs in another country, let alone allow them to send significant money home to relatives. In recent years, organisations have been formed to protect Pacific Island athletes around the world-for example, the Pacific Island Players Association, which acts as a union; the Pacific Rugby Players Welfare, which focuses on connecting players to reduce isolation and build communities; and the French Fijian Players Association, which does both of these things.

Pacific Islanders have been open to exploitation because of their marginal position in global labour markets-a legacy inherited from colonial times. Pacific peoples' different levels of access to the Australian labour market also reflect colonial legacies, with some Pacific Islanders able to access New Zealand citizenship and the TTTA based on their country of birth while others are excluded. Some Fijian interlocutors claimed that their exclusion was made worse by the preferential hiring of Samoan, Māori and Tongan men. However, the prominence of Fijians in elite Australian rugby, and the emergence of Fijian rugby organisations and teams in Australian cities, could signal that this is changing.

\section{Rugby Futures}

Rugby Futures, the organisation mentioned at the beginning of this chapter, exists on the margins of legitimacy. It runs rugby training clinics in several villages and in the major cities in Fiji. The 'futures' part of the training takes the form of a certificate in social work, awarded to attendees for taking part in religiously inflected presentations and discussions about drugs, alcohol and domestic violence. In a country where domestic violence and substance abuse are major problems, and where there is such a passionate interest in rugby among young men, the program has been widely welcomed into many villages.

The program purports to offer young Fijians a route into Australian professional rugby. In partnership with an Australian-based church group, Rugby Futures offers several dozen Fijian participants entry into Australia each year, officially as church workers, unofficially as rugby players. The link with the church means that the selected men are able to access religious worker visas, a special class of visa under the current Australian migration regime, that have far lower thresholds for sponsorship than other classes. However, most of the young men and women who travel this path hope to 
become professional rugby players through Rugby Futures' connections in the Australian industry. One of the Fijian athletes who arrived in the first year of the program signed a contract with a professional Australian club before moving to a higher-paying contract in Europe. His rapid rise has given the program credibility as a pathway to professional rugby—a reputation that the organisation actively encourages. Yet, the reality is very different, with migrants being forced to work for projects hand-picked by the program head and having little contact with the rugby industry.

Program participants in Australia are reluctant to speak out. Those who have complained in the past have found themselves sent to work as fruit pickers (with their salaries confiscated) in the north of Australia or back to Fiji to explain to family members why they have returned without fulfilling expectations. For voicing concerns about living and working conditions, one man had his passport confiscated. After breaking into the office to reclaim his passport, he ran away from the organisation and hid among the large Fijian community in another major Australian city. With few avenues for complaint, there is little protection given to isolated migrants. The problems are compounded by the fact that the organisation's head also acts as an unofficial agent for the players, making arrangements with amateur clubs in several Australian cities that want talented Fijian recruits in exchange for small unofficial signing bonuses for the players (reportedly up to AU\$5,000). However, no players reported receiving any of this money, and clubs that have not been able to pay have not received any players. This results in the majority of Fijians being concentrated in a few clubs.

Aspects of the rugby industry, such as the extremely short careers, possibility of very high wages for manual labour and absence of formal training programs, make it exceptional from the perspective of Australian labour markets and attractive to young itaukei men. Athletes at the top of the industry seem to enjoy a different status than other Fijian migrants. Sought out by clubs, fast-tracked for residency and protected by unions, top athletes can be both extremely well paid and secure. Success in rugby transforms the lives of individual players and the broader community in Fiji and Australia through the generous support that athletes give to family, church, villages and other migrants. Further, their success in sport increases the visibility of Pacific Islanders, thereby challenging negative stereotypes of this group. Yet, at the same time, their position is precarious. With one injury, a season without success or the arrival of a new coach, these men can lose their rugby careers. If this occurs, their 
position in Australian society can also be jeopardised, a precarity faced by other migrants, such as those in the horticultural industry as described by Victoria Stead in this volume.

The majority of young people to pass through the Rugby Futures program remain in Fiji, unable to navigate Australia's or other rugby-playing countries' migration regimes. ${ }^{57}$ Very few of those who enter Australia receive any financial benefit from their training and efforts in preparing themselves for a career in rugby. The program disciplines these young men in ways that are designed to make them employable as professional athletes, but opens few other opportunities in Australia. Rarely do they regret their time playing and training for such a culturally important sport as rugby, but the sacrifice of coming to Australia without gaining access to the labour market is a major one. Emanating from a country whose citizens enjoy few rights in contemporary migration regimes and labour markets, and having not been through an elite training program, they are essentially viewed as unskilled.

\section{Conclusion}

The coloniality of power is most visible at the margins of Australia's labour industry. The stories of Fijians being exploited while on seasonal work visas in Australia, as told in this chapter and in those by Stead, and Nishitani and Lee (this volume), have broader resonance with the experiences of the would-be professional athletes at the centre of this chapter. The potential rewards attached to short-term migration options for Fijians must be tempered by the existence of untrustworthy agents, confiscated passports and Pacific people isolated in rural and suburban Australia, fearful of reporting their mistreatment to authorities. Rugby migrants share with the majority of Fijian migrants an experience of being caught in a labour market that has historically used Pacific Island people (and Indigenous Australians) for work that white Australians did not want to do, and a migration regime that has long classified Fijians as unfit to live in Australia.

Connections that predate either nations' existence influence the relationship between Australia and Fiji, producing the landscape into which new migrants arrive. Some of these connections take the form of

57 For an account of similar dynamics in Samoa see Kwauk, "'Let Them See a Different Path”. 
legal and economic frameworks that produce uneven migratory regimes. Others are embodied in the Fijians who reside in Australia, supporting new arrivals and guiding their career trajectories and social lives (sometimes for their own benefit).

The contemporary lines that divide and contour the Australian labour market are influenced by neoliberal logics that dominate economic discussions and migration regimes that prioritise highly skilled migrants. These sets of logic presume the fundamental equality of people-that each individual starts from the same position in society. The success of some Fijians in this system helps to propagate the myth of their efficacy. However, this merely obscures the reality that the majority of Fijian migrants are only able to access certain parts of the economy and are confined to menial labour without any possibility of movement. Australia's colonial history and profound influence on the Pacific region leaves its mark on individuals and nations in ways that are not easily overcome.

\section{Bibliography}

Anae, Nicole. "Very Scanty Covering For the Chocolate Body": The Art of Burlesque and the Fijian Cricket Team in Australia, 1907-1908'. Australasian Drama Studies 63 (2013): 33-51.

Andrews, David L. and Michael L. Silk. Sport and Neoliberalism: Politics, Consumption, and Culture. Philadelphia: Temple University Press, 2012.

Australian Broadcasting Corporation. 'Seasonal farm workers receiving as little as \$9 a week after deductions, investigations reveals'. 7.30. 25 February 2016.

Banivanua Mar, Tracey. 'Shadowing Imperial Networks: Indigenous Mobility and Australia's Pacific Past'. Australian Historical Studies 46, no. 3 (2015): 340-55. doi.org/10.1080/1031461X.2015.1076012.

—. Violence and Colonial Dialogue: The Australian-Pacific Indentured Labor Trade. Honolulu: University of Hawai'i Press, 2007.

Bedford, Richard and Graeme Hugo. 'Population Movement in the Pacific: A Perspective on Future Prospects'. Wellington: Labour \& Immigration Research Centre, Te Pakapū a Mahi me Te Manene Rangahau, 2012.

Besnier, Niko. On the Edge of the Global: Modern Anxieties in a Pacific Island Nation. Stanford: Stanford University Press, 2011. 
' 'Sports, Bodies, and Futures: An Epilogue'. The Contemporary Pacific 26, no. 2 (2014): 435-44. doi.org/10.1353/cp.2014.0047.

Besnier, Niko, Daniel Guinness, Mark Hann and Uros Kovac. 'Rethinking Masculinity in the Neoliberal Order: Cameroonian Footballers, Fijian Rugby Players, and Senegalese Wrestlers'. Comparative Studies in Society and History 60, no. 4 (2018): 839-72. doi.org/10.1017/S0010417518000312.

Besnier, Niko and Susan Brownell. 'The Untold Story behind Fiji's Astonishing Gold Medal: While Fiji's National Identity Is Deeply Entangled with Rugby, Not Everyone Is Invited to Play'. SAPIENS, 19 August 2016, www.sapiens. org/culture/fiji-rugby-racial-sexual-politics/.

Blackledge, Paul. 'Rationalist Capitalist Concerns: William Cail and the Great Rugby Split of 1895'. The International Journal of the History of Sport 18, no. 2 (2001): 35-53. doi.org/10.1080/714001551.

Bourdieu, Pierre. Firing Back: Against the Tyranny of the Market 2. Translated by Loïc Wacquant. London: Verso, 2003.

'Community Information Summary: Fiji-Born'. Canberra: Department of Immigration and Citizenship, 2014. Accessed 14 March 2019, www.dss.gov. $\mathrm{au} /$ sites/default/files/documents/02_2014/fiji.pdf.

Connell, John. 'Emigration from the South Pacific: An Australian Perspective'. In Immigration: A Commitment to Australia. Canberra: Committee to Advise on Australia's Immigration Policies, Parliament of Australia, 1988.

Connell, John and Carmen Voigt-Graf. 'Towards Autonomy? Gendered Migration in Pacific Island Countries'. In Migration Happens: Reasons, Effects and Opportunities of Migration in the South Pacific, edited by Katarina Ferro and Margot Wallner, 43-62. Vienna: LIT Verlag, 2006.

Gammage, Bill. 'Early Boundaries of New South Wales'. Historical Studies 19, no. 77 (1981): 524-31. doi.org/10.1080/10314618108595657.

Gershon, Ilana. 'Neoliberal Agency'. Current Anthropology 52, no. 4 (2011): 537-55. doi.org/10.1086/660866.

Gershon, Ilana and Allison Alexy. 'The Ethics of Disconnection in a Neoliberal Age'. Anthropological Quarterly 84, no. 4 (2011): 799-808. doi.org/10.1353/ anq.2011.0056.

Grainger, Andrew. 'The Browning of the All Blacks: Pacific Peoples, Rugby, and the Cultural Politics of Identity in New Zealand'. PhD thesis, University of Maryland, 2008. 
Grainger, Andrew, Mark Falcous and Joshua Newman. 'Postcolonial Anxieties and the Browning of New Zealand Rugby'. The Contemporary Pacific 24, no. 2 (2012): 267-95. doi.org/10.1353/cp.2012.0029.

Guinness, Daniel. 'The Battle for Talent? Sport and Contested Nationality'. GlobalSport, 2016. Accessed 14 March 2019, global-sport.eu/?s=The+Battle+ for + Talent $\% 3 \mathrm{~F}+$ Sport+and + Contested + Nationality.

Guinness, Daniel, and Niko Besnier. 'Nation, Nationalism, and Sport: Fijian Rugby in the Local-Global Nexus', Anthropological Quarterly 89, no. 4 (2016): 1109-41. doi.org/10.1353/anq.2016.0070.

Hage, Ghassan. White Nation: Fantasies of White Supremacy in a Multicultural Society. Sydney: Pluto Press, 1998.

Hamer, Paul. "Unsophisticated and Unsuited": Australian Barriers to Pacific Islander Immigration from New Zealand', Political Science 66, no. 2 (2014): 93-118. doi.org/10.1177/0032318714554495.

Harvey, David. A Brief History of Neoliberalism. Oxford: Oxford University Press, 2005.

Horton, Peter. 'Rugby Union Football in the Land of the Wallabies, 1874-1949: Same Game, Different Ethos'. The International Journal of the History of Sport 26, no. 11 (2009): 1611-29. doi.org/10.1080/09523360903169925.

Kadiba, John. 'The Methodist Mission and the Emerging Aboriginal Church in Arnhem Land 1916-1977’. PhD thesis, Northern Territory University, 1998.

Kanemasu, Yoko and Gyozo Molnar. 'Double-Trouble: Negotiating Gender and Sexuality in Post-Colonial Women's Rugby in Fiji'. International Review for the Sociology of Sport 52, no. 4 (2015): 430-46. doi.org/10.1177/ 1012690215602680.

Kwauk, Christina. “'Let Them See a Different Path”: Social Attitudes towards Sport, Education and Development in Samoa'. Sport, Education and Society 21, no. 4 (2016): 644-60. doi.org/10.1080/13573322.2015.1071250.

Lake, Marilyn. 'The Australian Dream of an Island Empire: Race, Reputation, and Resistance'. Australian Historical Studies 46, no. 3 (2015): 410-24. doi.org/10.1080/1031461X.2015.1075222.

Lal, Brij. Broken Waves: A History of the Fiji Islands in the Twentieth Century. Honolulu: University of Hawai'i Press, 1992. 
Lawson, Stephanie. 'The Military Versus Democracy in Fiji: Problems for Contemporary Political Development'. In The Military and Democracy in Asia and the Pacific, edited by R. J. May and V. Selochan (2nd ed.), 132-47. Canberra, ACT: ANU E Press, 2004. doi.org/10.22459/MDAP.03.2004.09.

Mackay, Scott William. 'Australia in the Pacific: The Ambivalent Place of Pacific Peoples within Contemporary Australia'. PhD thesis, University of Melbourne, 2018.

Macpherson, Cluny and La'avasa Macpherson. The Warm Winds of Change: Globalisation in Contemporary Samoa. Auckland: Auckland University Press, 2010.

McDonald, Brent. 'Developing "Home-Grown" Talent: Pacific Island Rugby Labour and the Victorian Rugby Union'. The International Journal of the History of Sport 31, no. 11 (2014): 1332-44. doi.org/10.1080/09523367. 2014.923839 .

McDonald, Brent, B Belanji and L Derham. 'It's in the Blood: Negotiations of the Australian Rugby “Field” by Pacific Islanders'. TASA Conference Referred Proceedings, 2012.

McGuigan, Jim. 'The Neoliberal Self'. Culture Unbound, no. 6 (2014): 223-40.

Miller, Toby, Geoffrey Lawrence, Jim McKay and David Rowe. 'Modifying the Sign: Sport and Globalization'. Social Text, no. 17 (1999): 15-33.

Mirowski, Philip. 'Defining Neoliberalism'. In The Making of the Neoliberal Thought Collective, edited by Philip Mirowski and Dieter Plehwe, 417-55. Cambridge, MA: Harvard University Press, 2009.

Moore, Clive. Making Mala: Malaita in Solomon Islands, 1870s-1930s. Canberra: ANU Press, 2017. doi.org/10.22459/MM.04.2017.

Presterudstuen, Geir Henning. 'The Mimicry of Men: Rugby an Masculinities in Post-Colonial Fiji'. Global Studies 3 (2010): 237-48. doi.org/10.18848/18354432/CGP/v03i02/40692.

Quijano, Anibal. 'Coloniality and Modernity/Rationality'. Cultural Studies 21, no. 2-3 (2007): 168-78. doi.org/10.1080/09502380601164353.

_- 'Coloniality of Power, Eurocentrism, and Latin America'. Nepantla: Views from South 1, no. 3 (2000): 533-80. doi.org/10.1177/0268580900015002 005 .

Rose, Nikolas and Peter Miller. Governing the Present: Administering Economic, Social and Personal Life. Cambridge MA: Polity, 2008. 
Scherer, Jay and Steve Jackson. Globalization, Sport and Corporate Nationalism: The New Cultural Economy of the New Zealand All Blacks. Oxford: Peter Lang, 2010. doi.org/10.3726/978-3-0353-0000-0.

Schieder, Dominik. 'Fiji Islander Rugby Union Players in Japan: Corporate Particularities and Migration Routes'. Asia Pacific Journal of Sport and Social Science 3 (2014): 250-67. doi.org/10.1080/21640599.2014.982339.

Schubert, Mark. 'Griffith's Transnational Fijians: Between the Devil, the Deep Blue Sea ... and Their Pastors'. In Migration and Transnationalism: Pacific Perspectives, edited by Helen Lee and Steve Francis Tupai, 133-42. Canberra: ANU E Press, 2009. doi.org/10.22459/MT.08.2009.08.

Sharma, Akhilanand, Steven Coombs, Subhas Chandra and Manueli Sagaitu. 'Fiji: Evolution of Education from Colonial to Modern Times'. In Education in Australia, New Zealand and the Pacific, edited by Michael Crossley, Greg Hancock and Terra Sprague, 243-64. London; New York: Bloomsbury Academic, 2015.

Stephenson, Peta. 'Beyond Black and White: Aborigines, Asian-Australians and the National Imaginary'. PhD thesis, University of Melbourne, 2003.

Teaiwa, Katerina. Consuming Ocean Island: Stories of People and Phosphate from Banaba. Bloomington: Indiana University Press, 2015.

Teaiwa, Teresia. 'Articulated Cultures: Militarism and Masculinities in Fiji during the Mid-1990s'. Fijian Studies 3 (2005): 201-22.

Teaiwa, Teresia and Sean Mallon. 'Ambivalent Kinships? Pacific People in New Zealand'. In New Zealand Identities: Departures and Destinations, edited by J Liu, T McCreanor, T McIntosh and Teresia Teaiwa, 207-29. Wellington: Victoria University Press, 2005.

Trnka, Susanna. State of Suffering: Political Violence and Community Survival in Fiji. Ithaca: Cornell University Press, 2008.

Zavos, Spiro. 'The Browning of the Wallabies'. The Roar, 1 June 2007, www.theroar. com.au/2007/06/01/the-browning-of-the-wallabies/.

\section{Newspapers}

Fiji Times

Fox Sports

The Sydney Morning Herald 
This text is taken from Labour Lines and Colonial Power: Indigenous and Pacific Islander Labour Mobility in Australia, edited by Victoria Stead and Jon Altman, published 2019 by ANU Press, The Australian National University, Canberra, Australia.

doi.org/10.22459/LLCP.2019.09 